\title{
Meningkatkan Keaktifan dan Hasil Belajar Siswa pada Mata Pelajaran IPA Melalui Penerapan Metode Eksperimen Kelas V SDN Manggekompo Tahun 2017/2018
}

\author{
Muhamad Ajwar \\ STKIP Taman Siswa Bima \\ muhamadajwar06@gmail.com
}

\begin{abstract}
ABSTRAK
Keberhasilan pembelajaran tidak terlepas dari pemilihan metode yang tepat. Metode pembelajaran merupakan cara guru menyampaikan materi pelajaran untuk mencapai tujuan pembelajaran. Masalah dalam penelitian ini adalah Keaktifan dan hasil belajar IPA pada aspek kognitif siswa masih rendah sehingga perlu dicari solusi untuk kemajuan yang lebih baik, Tujuan dari penelitian ini adalah untuk meningkatkan keaktifan dan hasil belajar siswa pada mata pelajaran IPA melalui penerapan metode eksperimen kelas V SD Manggekompo tahun ajaran 2017/2018. Penelitian ini adalah penelitian tindakan kelas. Penelitian Tindakan Kelas adalah penelitian praktis yang dimaksudkan untuk memperbaiki pembelajaran di kelas. Penelitian ini merupakan salah satu upaya guru atau praktisi dalam bentuk berbagai kegiatan yang dilakukan untuk memperbaiki dan atau meningkatkan mutu pembelajaran di kelas. Peningkatan hasil belajar dari pra siklus ke siklus 1 tidak terlalu signifkan yaitu sebesar 21,43\%. Berdasarkan hasil belajar siklus II, guru dan peneliti menganalisis dan mengalami peningkatan yaitu $85,71 \%$. Dari pembahasan di atas dapat disimpulkan bahwa penerapan pembelajaran IPA menggunakan metode eksperimen dapat meningkatkan keaktifan dan hasil belajar siswa di SD Negeri Manggekompo. Penelitian tindakan kelas yang dilakukan di SD Negeri Manggekompo pada kelas $\mathrm{V}$ memiliki keterbatasan yang perlu diungkapkan diantaranya terdapat 4 siswa yang masih memiiliki hasil belajar di bawah KKM. Siswa yang masih belum tuntas akan ditangani secara khusus oleh guru kelas.
\end{abstract}

Kata Kunci: Belajar, Metode Belajar, dan Peningkatan Hasil Belajar

\section{PENDAHULUAN}

Salah satu aspek afektif yang memliki peranan penting dalam proses pembelajaran adalah keaktifan siswa. Keaktifan siswa menjadi hal yang sangat penting mengingat subjek utama dalam kegiatan belajar mengajar. Sedangkan guru akan berperan sebagai pembimbing dan mengamati bagaimana perkembangan siswanya. Mengacu pada pendapat di atas, maka dapat dikatakan bahwa dalam pembelajaran akan berjalan dengan baik apabila ada aktivitas siswa yang mendukung dalam pembelajaran, seperti aktif bertanya maupun mengemukakan pendapat.

Sekolah Dasar Negeri Manggekompo, merupakan salah satu sekolah di kabupaten Bima. Berdasarkan pengamatan di kelas, khususnya kelas $\mathrm{V}$ dapat diidentifikasi permasalahan-permasalahan yang terjadi. Permasalahan-permasalahan tersebut dapat dikemukakan sebagai berikut:
Kenyataan di lapangan saat pembelajaran IPA siswa kelas V SD Negeri Manggekompo didapatkan guru mata pelajaran IPA yang menggunakan metode ceramah untuk menyampaikanmateri. Materi IPA yang membutuhkan praktik untuk memberikan pengalaman, disampaikan guru dengan menjelaskan secara garis besar.

Pembelajaran dikelas juga berpusat pada guru, sehingga menyebabkan keaktifan siswa dalam pembelajaran relatif rendah. Siswa di dalam kelas hanya mendengarkan penjelasan dari guru sehingga tidak adanya sebuah interaksi dalam pembelajaran. Siswa yang hanya mendengarkan materi yang disampaikan oleh guru tidak dapat menjawab pertanyaan dari guru secara optimal.

Berdasarkan wawancara dengan beberapa siswa kelas $\mathrm{V}$ dikatakan bahwa mata pelajaran Ilmu Pengetahuan Alam merupakan mata pelajaran yang dianggap sulit selain mata 
pelajaran matematika. Hal ini disebabkan oleh penyajian materi IPA yang kurang menarik dan membosankan, akhirnya terkesan sulit dan menakutkan bagi siswa, sehingga minat belajar menjadi berkurang dan tidak tertarik dengan mata pelajaran IPA.

Hasil wawancara terhadap siswa juga didapatkan bahwa siswa merasa bosan dalam pembelajaran, sehingga mereka cenderung tidak memperhatikan saat guru menyampaikan pelajaran. Hal ini dibuktikan ketika pembelajaran ada beberapa siswa yang bermain dengan mainannya di dalam laci meja.

Hasil wawancara peneliti terhadap guru mata pelajaran IPA kelas V didapatkan bahwa rata-rata hasil nilai siswa yang berupa angka masih tergolong rendah dibandingkan dengan mata pelajaran lain. Nilai IPA yang didapat di SD Negeri Manggekompo belum sepenuhnya memenuhi batas ketuntasan minimal yaitu 65 .

Berdasarkan hasil belajar Ilmu Pengetahuan Alam siswa kelas V SD Negeri Manggekompo pada saat ulangan harian, dari 28 siswa didapatkan 11 siswa yang mendapatkan nilai di atas batas ketuntasan dan 17 siswa masih di bawah batas ketuntasan. Untuk menangani masalah-masalah tersebut guru harus memilih secara tepat metode pembelajaran yang akan digunakan.

Berkaitan dengan hal tersebut, perlu diupayakan suatu bentuk pembelajaran yang tidak hanya mampu secara materi saja tetapi juga mengutamakan kreativitas setiap siswa, sehingga selain diharapkan mampu meningkatkan hasil belajar juga diharapkan dapat membuat siswa aktif terlibat dalam proses kegiatan pembelajaran semaksimal mungkin.

Metode pembelajaran eksperimen atau percobaan sebagai salah satu metode pembelajaran yang cocok diterapkan untuk menangani masalah-masalah yang telah ditemukan peneliti dalam pembelajaran. Masalah yang ditemukan oleh peneliti yaitu kurangnya keaktifan dan hasil belajar siswa, metode pembelajaran guru yang hanya menyampaikan materi saja tanpa adanya praktik, maka dengan eksperimen dapat mengatasi hal tersebut dengan mengajak siswa menemukan konsep dan mengembangkan ketrampilan dasar melalui percobaan.

Berdasarkan uraian di atas, maka penulis merasa perlu mengadakan penelitian dengan judul: "Meningkatkan Keaktifan dan Hasil Belajar Siswa Pada Mata Pelajaran IPA Melalui Penerapan Metode Eksperimen Kelas V SD Manggekompo Tahun Ajaran 2017/2018”

\section{Pembelajaran IPA di SD}

IPA diperlukan dalam kehidupan sehari-hari untuk memenuhi kebutuhan manusia, sehingga IPA dapat digunakan sebagai solusi untuk memecahkan suatu masalah. Oleh karena itu, penerapan IPA harus dilakukan dengan bijaksana agar tidak berdampak buruk pada lingkungan. Pada tingkat Sekolah Dasar pembelajaran IPA harus diarahkan pada pengalaman belajar. KPembelajaran IPA sebaiknya dilakukan dengan menemukan masalah, hal ini untuk menumbuhkan kemampuan berpikir, bekerja dan bersikap secara ilmiah. Oleh karena itu, menurut Sulistyorini (2007: 39), pembelajaran IPA di SD menekankan pada pemberian pengalaman belajar secara langsung melalui penggunaan dan pengembangan ketrampilan proses dan sikap ilmiah.

\section{Keaktifan Siswa}

Keaktifan siswa dalam pembelajaran sangatlah berpengaruh dalam pencapaian hasil belajar. Keaktifan berasal dari kata aktif dan mendapatkan imbuhan ke-an yang mempunyai arti dalam kamus Besar Bahasa Indonesia adalah giat (bekerja berusaha). Jadi dapat dinyatakan bahwa keaktifan adalah keadaan dimana siswa bekerja berusaha menjadi aktif. Penilaian proses pembelajaran dilihat dari sejauh mana keaktifan siswa dalam mengikuti pembelajaran. Keaktifan siswa dapat dilihat ketika siswa berperan dalam pembelajaran seperti aktif bertanya kepada siswa maupun guru, mau berdiskusi kelompok dengan siswa lain, mampu menemukan masalah serta dapat memecahkan masalah tersebut, dan dapat menerapkan apa yang telah diperoleh untuk menyelesaikan persoalan yang dihadapinya (Nana Sudjana, 2009:61). Dari beberapa pendapat ahli di atas dinyatakan bahwa keaktifan siswa adalah suatu kegiatan yang 
dilakukan siswa untuk berusaha menjadi aktif dalam proses pembelajaran. Siswa harus aktif bertanya, mempertanyakan, mengemukakan gagasan, mampu berinteraksi dengan siswa lain serta mampu memecahkan masalah yang dijumpainya dalam pembelajaran.

\section{Metode Eksperimen}

Eksperimen atau percobaan adalah suatu perkembangan ilmu pengetahuan dan teknologi agar menghasilkan suatu produk yang dapat dinikmati masyarakat dengan aman (Mulyani Sumantri, 1999: 157). Metode ekpserimen atau percobaan diartikan sebagai cara belajar mengajar yang melibatkan siswa dengan mengalami dan membuktikan sendiri proses dan hasil belajar itu (Mulyani Sumantri, 1999: 157).

Dari berbagai pendapat tersebut dinyatakan bahwa metode eksperimen adalah suatu cara belajar yang melibatkan siswa untuk melakukan percobaan dengan mengamati proses dan hasil percobaan itu, yang kemudian siswa mempresentasikan hasil percobaannya dan dievaluasi oleh guru.

\section{METODELOGI PENELITIAN}

Jenis penelitian ini adalah penelitian tindakan kelas. Penelitian Tindakan Kelas adalah penelitian praktis yang dimaksudkan untuk memperbaiki pembelajaran di kelas. Penelitian ini merupakan salah satu upaya guru atau praktisi dalam bentuk berbagai kegiatan yang dilakukan untuk memperbaiki dan atau meningkatkan mutu pembelajaran di kelas. Adapun subjek penelitian dilakukan di Siswa Kelas V SDN Manggekompo Tahun 2017/2018, berjumlah 28 orang yang terdiri dari 11 orang laki-laki, dan 17 orang perempuan. Penelitian tindakan kelas ini direncanakan akan dilaksanakan dalam dus siklus, akan tetapi jika pada siklus pertama sudah memperoleh nilai sesuai standar KKM yang ditetapkan yaitu 70 maka penelitian pada siklus ke dua dan ke tiga tidak perlu dilakukan lagi. Untuk pengumpulan data proses pelaksanaan tindakan dan untuk mengetahui hasil belajar setelah pelaksanaan tindakan, digunakan beberapa instrumen penelitian seperti; Tes tulis dan lembar observasi penelitian.

\section{PEMBAHASAN HASIL PENELITIAN}

\section{Hasil Penelitian Siklus I}

Sebelum merencanakan siklus I peneliti melakukan kegiatan pra siklus dan meminta nilai hasil belajar siswa pada guru. Nilai hasil belajarnya adalah sebagai berikut:

Tabel 1. Hasil Belajar Siswa Pra Siklus

\begin{tabular}{|l|c|}
\hline Jumlah Siswa & 28 \\
\hline KKM & 65 \\
\hline Nilai Tertinggi & 100 \\
\hline Nilai Terendah & 20 \\
\hline Jumlah Siswa Tuntas & 10 \\
\hline Jumlah Siswa Tidak Tuntas & 18 \\
\hline Capaian Ketuntasan Belajar Siswa & $35,71 \%$ \\
\hline Capaian Siswa Tidak Tuntas Belajar & $64,28 \%$ \\
\hline
\end{tabular}

Berdasarkan hasil tersebut maka peneliti merencanakan kegiatan siklus I. Dalam perencanaan tindakan ini, guru sebagai pelaksana tindakan dan peneliti sebagai peneliti. Sebelum melaksanakan tindakan, terlebih dahulu peneliti dan guru membuat Rencana Pelaksanaan Pembelajaran menggunakan metode eksperimen. Rencana Pembelajaran siklus I dilaksanakan dua kali pertemuan yang masing- masing waktunya 2 x 35 menit, baik pertemuan pertama maupun pertemuan kedua berisi tentang standar kompetensi, kompetensi dasar, indikator, materi ajar, metode, langkahlangkah pembelajaran, penilaian, alat, bahan, sumber, LKS, dan soal tes. Siklus I dilakukan 2 kali pertemuan. Evaluasi dilakukan pada akhir siklus untuk mengetahui peningkatan hasil belajar siswa. Siswa terlihat aktif dalam pembelajaran, siswa sangat antusias dalam pembelajaran karena pembelajaran kali ini berbeda dengan pembelajaran biasanya yaitu tidak hanya mendengarkan penjelasan guru saja namun juga siswa melakukan praktik.

Data analisis keaktifan siswa secara keseluruhan siklus I menunjukan bahwa ratarata keaktifan siswa siklus 1 secara keseluruhan sebesar 55\%. Hasil belajar siswa diperoleh setelah siswa melakukan tes hasil belajar siklus I yaitu pada akhir pertemuan kedua. hasil tes siklus 1 yang diikuti oleh 28 siswa dengan 16 siswa yang dapat dinyatakan sudah mencapai nilai ketuntasan dengan capaian $57,14 \%$ serta siswa yang belum tuntas ada 8 siswa dengan capaian sebesar 42,85\%. Berdasarkan hasil 
belajar siswa siklus I dapat dijelaskan bahwa pembelajaran IPA menggunakan metode eksperimen dapat meningkatkan hasil belajar siswa kelas V SD Negeri Manggekompo. Peningkatan hasil belajar siklus I sebesar $57,14 \%$, kondisi awal sebelum tindakan rata-rata hasil belajar siswa $35,71 \%$ meningkat menjadi $57,14 \%$ pada siklus I. namun rata-rata hasil belajar tersebut belum memenuhi kriteria keberhasilan bahwa jumlah siswa yang mendapat nilai lebih dari KKM 65 masih kurang.

\section{Hasil Penelitian Siklus II}

Rencana Pelaksanaan Pembelajaran siklus II baik pertemuan pertama maupun pertemuan kedua berisi tentang standar kompetensi, kompetensi dasar, indikator, materi ajar, metode, langkah-langkah pembelajaran, penilaian, alat, bahan, sumber, LKS, dan soal tes. Rencana pembelajaran yang dibuat guru disesuaikan dengan tujuan pembelajaran setiap pertemuanya. Hal ini disesuaikan dengan kondisi kelas dan indikator yang diharapkan tercapai. Hal yang harus dipersiapkan selanjutnya adalah mempersiapkan media. Dalam siklus ini media yang harus dipersiapkan adalah alat dan bahan untuk percobaan membuktikan cahaya dapat dipantulkan, cahaya dapat dibiaskan serta cahaya dapat diuraikan. Siklus II dilakukan 2 kali pertemuan. Evaluasi dilakukan pada akhir siklus untuk mengetahui peningkatan hasil belajar siswa. Observasi dilaksanakan oleh peneliti dan guru sebagai pelaksana tindakan. Hal-hal yang di observasi adalah aktivitas siswa selama proses pembelajaran dengan menggunakan metode eksperimen. Observasi pada siklus II yaitu hasil observasi setiap tindakan pada siklus.

Berdasarkan hasil penelitian siklus I dan siklus II terdapat peningkatan baik dari keaktifan maupun hasil belajar, capaian keaktifan siswa siklus I secara keseluruhan sebesar 55\% dan meningkat menjadi 95\% pada siklus II. Nilai hasil belajar siswa mengalami penigkatan yang dari siklus I yang keseluruhanya sebesar 57,14\% meningkat menjadi $85.71 \%$ pada siklus II. Berdasarkan capaian keaktifan siswa siklus I secara keseluruhan sebesar 55\% dan meningkat menjadi 95\% pada siklus II.

\section{PENUTUP}

Penelitian yang dilaksanakan di kelas V SD Negeri Manggekompo ini bertujuan untuk meningkatkan keaktifan dan hasil belajar pada ranah kognitif (pemahaman terhadap materi) siswa pada pelajaran IPA pokok bahasan sifatsifat cahaya melalui metode eksperimen. Penelitian ini juga bertujuan untuk mendeskripsikan capaian keaktifan siswa dan hasil belajar ranah kognitif melalui penerapan metode eksperimen. Penelitian ini merupakan penelitian tindakan kelas yang diawali dengan observasi awal, pembuatan perencanaan, dan pelaksanakaan tindakan. Tindakan dilakukan dalam 2 siklus, dan setiap siklus terdiri dari 2 kali pertemuan. Pelaksanaan tindakan setiap siklusnya disesuaikan dengan tujuan pembelajaran pada setiap siklus. Instrumen yang digunakan pada penelitian ini adalah, LKS, RPP, soal tes setiap akhir siklus, lembar observasi kegiatan guru dan siswa. Penelitian juga dibantu dengan data pada saat observasi awal. Data-data yang dihasilkan dianalisis untuk mengetahui perkembangan setiap proses dan hasil yang diperoleh dalam setiap siklusnya.

Peningkatan hasil belajar dari pra siklus ke siklus 1 tidak terlalu signifkan yaitu sebesar 21,43\%. Berdasarkan hasil belajar siklus II, guru dan peneliti menganalisis dan mengalami peningkatan yaitu $85,71 \%$. Dari pembahasan di atas dapat disimpulkan bahwa penerapan pembelajaran IPA menggunakan metode eksperimen dapat meningkatkan keaktifan dan hasil belajar siswa di SD Negeri Manggekompo. Penelitian tindakan kelas yang dilakukan di SD Negeri Manggekompo pada kelas V memiliki keterbatasan yang perlu diungkapkan diantaranya terdapat 4 siswa yang masih memiiliki hasil belajar di bawah KKM. Siswa yang masih belum tuntas akan ditangani secara khusus oleh guru kelas.

\section{DAFTAR PUSTAKA}

Bloom (Purwanto, 2012). Evaluasi Hasil Belajar. Yogyakarta : Pustaka Pelajar.

Budi Prasojo. (2004). Teori dan Aplikasi Fisika untuk Kelas 2 SMP. Jakarta: Yudhistira 
Daryanto. (2011). Penelitian Tindakan Kelas dan

Penelitian TindakanSekolah Beserta

Contoh-Contohnya. Yogyakarta: Gava

Media.

Gaggne \& Briggs (JamilSuprihatiningrum, 2013). Strategi Pembelajaran: Teori Aplikasi. Yogyakarta: Ar Russ Media

Maslichah Asy'ari. (2006). Penerapan Pendekatan Sains Teknologi Masyarakat Dalam Pembelajaran Sains Di Sekolah Dasar. Yogyakarta: Universitas Sanata Dharma Yogyakarta

MulyaniSumantri. (1999). Strategi Belajar Mengajar. Jakarta: Direktorat

Jenderal Pendidikan Tinggi

Moedjono.(1992). Strategi Belajar Mengajar. Jakarta: Direktorat Jenderal Pendidikan Tinggi

Nana sudjana.(2009).Penilaian Hasil Proses Belajar Mengajar. Bandung: PT Remaja Rosdakarya

Nugrahini Dwi Wijayanti. (2012). Peningkatan Keaktifan Siswa Menggunakan

Pendekatan Kontekstual Berbasis Hands on Activity pada Pembelajaran IPA Tema Pencemaran Air Kelas VII di SMP N 1 Seyegan. Skripsi, tidak diterbitkan, Yogyakarta, UNY.

Oemar Hamalik. (2010). Proses Belajar Mengajar.Jakarta : BumiAksara

Suharsimi Arikunto, Suhardjono, dan Supardi. (1995). Penelitian Tindakan Kelas. Jakarta: PT. Bumi Aksa

Suharsimi Arikunto. (2009). -dasar Evaluasi Pendidikan. Jakarta: Rineka Cipta

Sri Sulistyorini dan Supartono.(2007). Model Pembelajaran IPA danPenerapannya dalam KTSP. Yogyakarta: Tiara Wacana

S. Rositawaty dan Aris Muharam. (2008). Senang Belajar Ilmu Pengetahuan Alam 5: untuk Kelas V Sekolah Dasar/ Madrasah Ibtidaiyah. Jakarta: Pusat Perbukuan Departemen Pendidikan Nasional

Trianto.(2007).ModelPembelajaran Terpadu dalam Teori dan Praktek.Jakarta:Prestasi PustakaRaya
Wina Sanjaya. (2009). Penelitian Tindakan Kelas. Jakarta: Kencana Prenada Media Group 